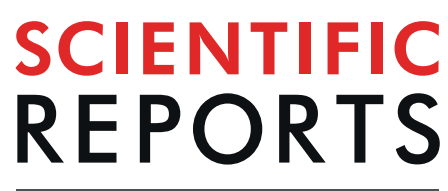

natureresearch

\title{
Raman and X-ray diffraction study of pressure-induced phase transition in synthetic $\mathrm{Mg}_{2} \mathrm{TiO}_{4}$
}

\author{
Ching-Pao Wang ${ }^{1 *}$, Sean R. Shieh ${ }^{1,2^{*}}$, Anthony C. Withers ${ }^{1,3}$, Xi Liu ${ }^{4,5}$, Dongzhou Zhang ${ }^{6}$, \\ Sergey N. Tkachev ${ }^{7}$, Abd-Erraouf Djirar ${ }^{1}$, Tianqi Xie $^{1}$ \& Justin D. Rumney ${ }^{1}$
}

Synthetic $\mathrm{Mg}_{2} \mathrm{TiO}_{4}$ qandilite was investigated to 50 and 40.4 GPa at room temperature using Raman spectroscopy and X-ray diffraction, respectively. The Raman measurements showed that cubic $\mathrm{Mg}_{2} \mathrm{TiO}_{4}$ spinel transforms to a high pressure tetragonal (14/amd, No.141) phase at $14.7 \mathrm{GPa}$. Owing to sluggish kinetics at room temperature, the spinel phase coexists with the tetragonal phase between 14.7 and 24.3 GPa. In the X-ray diffraction experiment, transformation of the cubic $\mathrm{Mg}_{2} \mathrm{TiO}_{4}$ to the tetragonal structure was complete by $29.2 \mathrm{GPa}, \sim 5 \mathrm{GPa}$ higher than the transition pressure obtained by Raman measurements, owing to slow kinetics. The obtained isothermal bulk modulus of $\mathrm{Mg}_{2} \mathrm{TiO}_{4}$ spinel is $K_{\mathrm{T} 0}=148(3) \mathrm{GPa}$ when $K_{\mathrm{T} 0}{ }^{\prime}=6.6$, or $K_{\mathrm{T} 0}=166(1) \mathrm{GPa}$ when $K_{\mathrm{T} 0}{ }^{\prime}$ is fixed at 4. The isothermal bulk modulus of the high-pressure tetragonal phase is calculated to be $209(2) \mathrm{GPa}$ and $\mathrm{V}_{0}=270(2) \AA^{3}$ when $K_{\mathrm{TO}}{ }^{\prime}$ is fixed at 4 , and the volume reduction on change from cubic to tetragonal phase is about $9 \%$. The calculated thermal Grüneisen parameters $\left(\gamma_{t h}\right)$ of cubic and tetragonal $\mathrm{Mg}_{2} \mathrm{TiO}_{4}$ phases are 1.01 and 0.63 . Based on the radii ratio of spinel cations, a simple model is proposed to predict post-spinel structures.

$\mathrm{Mg}_{2} \mathrm{TiO}_{4}$ (qandilite) is an oxospinel with excellent dielectric properties that are widely used in satellite communications, mobile phones and wireless communication systems ${ }^{1,2}$. In addition, $\mathrm{Mg}_{2} \mathrm{TiO}_{4}$ spinel can form a high-temperature superconducting epitaxial thin film ${ }^{3,4}$, and is a good candidate for thin film phosphor in optoelectronic applications due to its red emission at high temperature ${ }^{5}$. Natural $\mathrm{Mg}_{2} \mathrm{TiO}_{4}$ was discovered in the Kangerdlugssuaq region of East Greenland ${ }^{6}$ and named qandilite after the Qandil Group of metamorphic rocks at Qala-Dizeh region of $\mathrm{Iraq}^{7}$. At ambient pressure, $\mathrm{Mg}_{2} \mathrm{TiO}_{4}$ exhibits as a tetragonal structure below $660^{\circ} \mathrm{C}$ but as a cubic structure above $660^{\circ} \mathrm{C}^{8,9}$. The cubic phase breaks down to $\mathrm{MgTiO}_{3}$ (geikielite) and $\mathrm{MgO}$ (periclase) with increasing pressure ${ }^{10}$. Synthetic $\mathrm{Mg}_{2} \mathrm{TiO}_{4}$ qandilite has inverse spinel structure ${ }^{\mathrm{T}}\left(\mathrm{Mg}^{2+}\right)^{\circ}\left(\mathrm{Mg}^{2+}, \mathrm{Ti}^{4+}\right) \mathrm{O}_{4}{ }^{9,11,12}$, which means that $\mathrm{Mg}^{2+}$ cations occupy both tetrahedral $(\mathrm{T})$ and octahedral $(\mathrm{O})$ sites, while $\mathrm{Ti}^{4+}$ cations are present only in octahedral sites. The isothermal bulk modulus of cubic qandilite was reported to be $169 \mathrm{GPa}$, based on empirical calculations ${ }^{13}$, and $175 \mathrm{GPa}$ in a diamond anvil cell study ${ }^{14}$, whereas the adiabatic bulk modulus of qandilite was determined to be $152 \mathrm{GPa}$ by ultrasonic measurements ${ }^{15}$. However, no phase transformation was found in previous studies, even though three major post-spinel structures, namely $\mathrm{CaTi}_{2} \mathrm{O}_{4}(\mathrm{CT}$; space group $\mathrm{Cmcm}$ ), $\mathrm{CaMn}_{2} \mathrm{O}_{4}\left(\mathrm{CM}\right.$; space group Pbcm), and $\mathrm{CaFe}_{2} \mathrm{O}_{4}(\mathrm{CF}$; space group Pnma) have been proposed to be stable under high pressure environments ${ }^{16}$. Unlike CM and CF structures, most CT phases have not been discovered at room temperature but instead under higher temperatures ${ }^{17-19}$. In addition to the orthorhombic structures, a tetragonal structure (space group I4 $4_{1} / \mathrm{amd}$ ) was reported for post-spinel phases at high pressure conditions as an intermediate phase $\mathrm{e}^{20-25}$. The post-spinel structures attract considerable attention because they are isostructural with ringwoodite, which is the most abundant phase, comprising approximately $50-60 \%$ by volume, in the Earth's transition zone (400-600 km in depth) ${ }^{26}$. Furthermore, knowledge of the post-spinel phase may have important implications for structure and dynamics of the interior of the exoplanets. Because of the geological and material importance of $\mathrm{Mg}_{2} \mathrm{TiO}_{4}$ phases, high pressure measurements of phase stability, structure determination, and

\footnotetext{
${ }^{1}$ Department of Earth Sciences, University of Western Ontario, London, Ontario, N6A 5B7, Canada. ${ }^{2}$ Department of Physics and Astronomy, University of Western Ontario, London, Ontario, N6A 5B7, Canada. ${ }^{3}$ Bayerisches Geoinstitut, Universität Bayreuth, Bayreuth, Germany. ${ }^{4} \mathrm{Key}$ Laboratory of Orogenic Belts and Crustal Evolution, MOE, Peking University, Beijing, 100871, China. ${ }^{5}$ School of Earth and Space Sciences, Peking University, Beijing, 100871, China. ${ }^{6}$ School of Ocean and Earth Science and Technology, Hawai'i Institute of Geophysics and Planetology, University of Hawaii at Manoa, Honolulu, HI, 96822, United States. ${ }^{7}$ Center for Advanced Radiation Sources, University of Chicago, Chicago, Illinois, 60637, United States. *email: jinbaow@gmail.com; sshieh@uwo.ca
} 


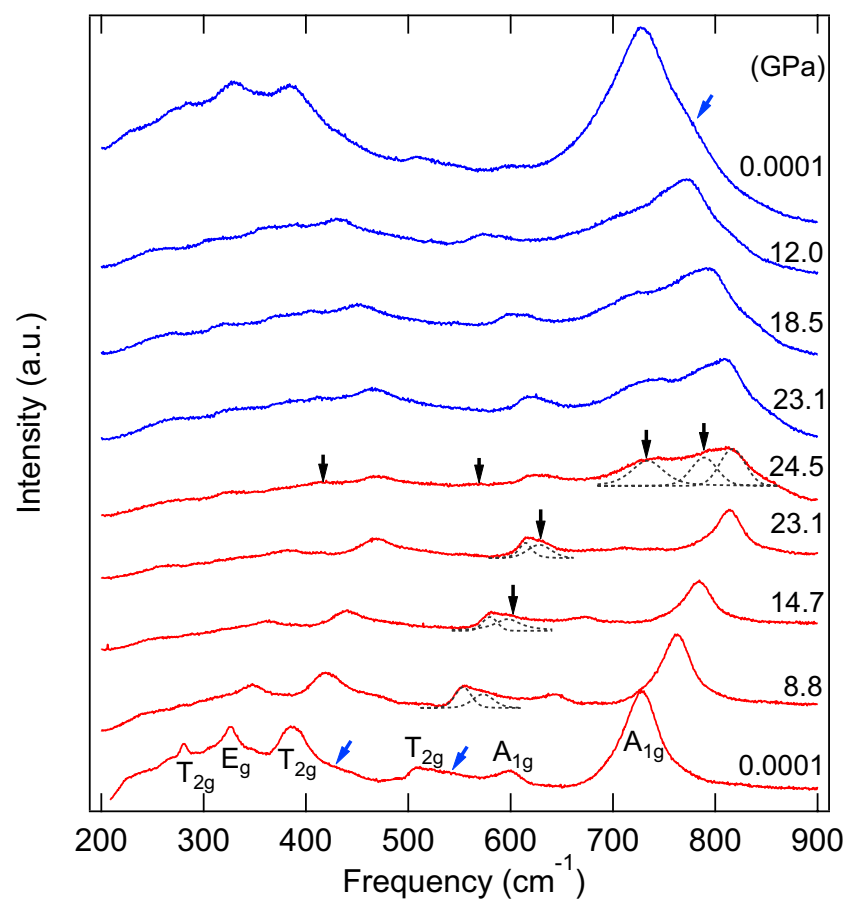

Figure 1. Raman spectra of $\mathrm{Mg}_{2} \mathrm{TiO}_{4}$ at pressure to $24.5 \mathrm{GPa}$ and room temperature. A new Raman peak appeared at $14.7 \mathrm{GPa}$ and four additional modes of the high-pressure phase appeared at $24.5 \mathrm{GPa}$. Red: compression, blue: decompression. Blue and black arrows indicate the Raman modes of spinel and tetragonal phases, respectively.

thermodynamic properties are needed in the $\mathrm{Mg}_{2} \mathrm{TiO}_{4}$ system. In this study, in situ high- pressure Raman measurements and equations of states of both spinel and post-spinel structures of synthetic $\mathrm{Mg}_{2} \mathrm{TiO}_{4}$ qandilite were investigated at room temperature. The post-spinel phase was identified and a model for prediction of post-spinel structure is also reported.

\section{Result and Discussion}

Two Raman measurements were conducted at pressure to $24.5 \mathrm{GPa}$ and $50 \mathrm{GPa}$, respectively. Group theory predicts that for normal spinels at the $\Gamma$ point of the Brillouin zone ${ }^{27}$ :

$$
\Gamma=\mathrm{A}_{1 \mathrm{~g}}(\mathrm{R})+\mathrm{E}_{\mathrm{g}}(\mathrm{R})+\mathrm{T}_{1 \mathrm{~g}}+3 \mathrm{~T}_{2 \mathrm{~g}}(\mathrm{R})+2 \mathrm{~A}_{u}+\mathrm{E}_{u}+4 \mathrm{~T}_{1 u}+\mathrm{T}_{1 u}+2 \mathrm{~T}_{2 u}
$$

where $\mathrm{R}$ denotes Raman-active modes and $\mathrm{u}$ denotes infrared-active modes. Therefore, five Raman bands are predicted for the normal spinels. However, cation disorder in the inverse spinel is expected to cause splitting of the $\mathrm{A}_{1 \mathrm{~g}}$ mode ${ }^{28-31}$. In this study, two $\mathrm{A}_{1 \mathrm{~g}}$, one $\mathrm{E}_{\mathrm{g}}$, and three $\mathrm{T}_{2 \mathrm{~g}}$ were observed for $\mathrm{Mg}_{2} \mathrm{TiO}_{4}$ spinel, and, in addition, two weak peaks at the shoulders of $\mathrm{T}_{2 \mathrm{~g}}\left(432\right.$ and $\left.546 \mathrm{~cm}^{-1}\right)$ were present (blue arrows in Fig. 1). The higher frequency peaks of $\mathrm{A}_{1 \mathrm{~g}}$ modes are assigned to stretching of the $\mathrm{MgO}_{4}$ tetrahedron and the split $\mathrm{A}_{1 \mathrm{~g}}$ mode is found at about $596 \mathrm{~cm}^{-1}$ in our measurements. The $\mathrm{E}_{\mathrm{g}}$ mode corresponds to a symmetric bending vibration of the oxygens within tetragonal units. The $\mathrm{T}_{2 \mathrm{~g}}$ near $506 \mathrm{~cm}^{-1}$ is caused by an asymmetric bending of $\mathrm{O}-\mathrm{Mg}$-O bonds and the other $\mathrm{T}_{2 \mathrm{~g}}$ near $281 \mathrm{~cm}^{-1}$ is assigned to the translation between $\mathrm{TiO}_{6}$ octahedron and $\mathrm{Mg}$ cation. The $\mathrm{T}_{2 \mathrm{~g}}$ near $385 \mathrm{~cm}^{-1}$ arises from the opposing translations between cations and oxygens along one direction of the lattice. The two different shoulders of $\mathrm{T}_{2 \mathrm{~g}}$ are likely related to cation substitutions. When $\mathrm{Mg}_{2} \mathrm{TiO}_{4}$ spinel was compressed to $14.7 \mathrm{GPa}$, a new peak appeared close to $595 \mathrm{~cm}^{-1}$. Upon further compression to $24.5 \mathrm{GPa}$, four additional new peaks were observed, strongly suggesting a new phase. To test whether the new high-pressure phase can be quenchable, the sample was gradually decompressed to ambient pressure, after which a shoulder of high frequency $\mathrm{A}_{1 \mathrm{~g}}$ from the high pressure phase was retained, suggesting that the new phase did not fully back-transform and some amount of the new phase coexisted with the spinel phase (Fig. 1). The second Raman measurements were conducted to $50 \mathrm{GPa}$ and the results are shown in Fig. 2. Phase transition again occurred near $15 \mathrm{GPa}$, marked by the appearance of a single new peak. The full spectrum of the new phase was evident at $24.3 \mathrm{GPa}$, in agreement with the first run, and the new phase persisted to $50 \mathrm{GPa}$. However, upon decompression the high-pressure phase was retained to about $18.7 \mathrm{GPa}$ and most of the features were diminished with further decompression, except for the broad $\mathrm{A}_{1 \mathrm{~g}}$ peak near $700-800 \mathrm{~cm}^{-1}$. Minor $\mathrm{MgTiO}_{3}$ impurity was also observed during the second Raman measurement at 8.8 and $12.2 \mathrm{GPa}$, giving rise to the weak feature marked by an asterisk in the second set of Raman measurements. A previous Raman study of $\mathrm{MgTiO}_{3}$ showed no phase change at pressure to $27 \mathrm{GPa}^{32}$, suggesting that even if there is minor $\mathrm{MgTiO}_{3}$ impurity, it should not have any contribution to the transition pressure. 


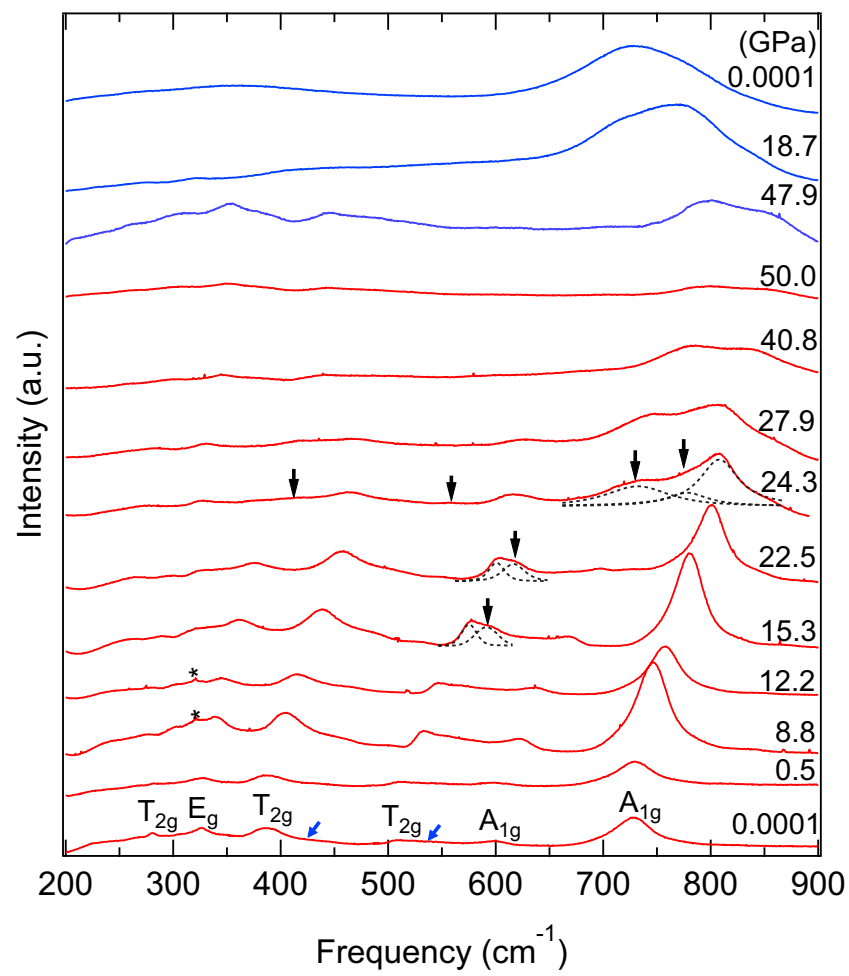

Figure 2. Raman spectra of $\mathrm{Mg}_{2} \mathrm{TiO}_{4}$ at pressure to $50.0 \mathrm{GPa}$ and room temperature. A new Raman mode appeared at $15.3 \mathrm{GPa}$ and four new peaks appeared at $24.3 \mathrm{GPa}$. Red: compression, blue: decompression, asterisk symbols (*) only observed at 8.8 and $12.2 \mathrm{GPa}$ are $\mathrm{MgTiO}_{3}$. Blue arrows are the shoulders of $\mathrm{Mg}_{2} \mathrm{TiO}_{4} \mathrm{Raman}$ modes. Blue and black arrows indicate the Raman modes of spinel and tetragonal phases, respectively.

To better understand the phase transition boundary, the frequency shifts as a function of pressure are plotted in Fig. 3. A single new peak observed at slightly higher frequency near $595 \mathrm{~cm}^{-1}$ at about $14.7 \mathrm{GPa}$ and is assigned to the new phase. A discontinuity was clearly observed near $24.3 \mathrm{GPa}$, as evidenced by four additional modes near $413,558,737$, and $836 \mathrm{~cm}^{-1}$. Our Raman data suggest that the new phase only partially transformed at about $14.7 \mathrm{GPa}$, and that the transformation is very sluggish. A two-phase mixture therefore persists between 14.7 and $24.3 \mathrm{GPa}$. The decompression results showed that the high-pressure phase was partly quenchable, and both spinel and high-pressure phases coexisted to ambient pressure. Four high-pressure modes and six cubic bands were found in the quenched Raman spectra based on two sets of Raman measurements, but the peak at about $500 \mathrm{~cm}^{-1}$, which coincides with the position of a peak in compression data, appeared only below $4 \mathrm{GPa}$. Since this is a first-order phase transition for $\mathrm{Mg}_{2} \mathrm{TiO}_{4}$, we were then able to obtain the slopes of pressure dependence $\mathrm{d}_{\mathrm{i}} /$ $\mathrm{dP}$ values based on two different datasets of curve fits.

The high-pressure phase of $\mathrm{Mg}_{2} \mathrm{TiO}_{4}$ could have a tetragonal structure, based on the splitting of $\mathrm{MgO}_{4}$ modes. Previous studies on $\mathrm{ZnGa}_{2} \mathrm{O}_{4}{ }^{20}$ and $\mathrm{MgCr}_{2} \mathrm{O}_{4}{ }^{22}$ also suggested a cubic to tetragonal transition at high pressure and room temperature. Our X-ray diffraction analyses (see below) suggest that the high-pressure phase is a tetragonal spinel ( $\mathrm{I}_{1} / \mathrm{amd}$, No.141). The new peak at $413 \mathrm{~cm}^{-1}$ splits from $\mathrm{E}_{\mathrm{g}}$ at $24.3 \mathrm{GPa}$ due to the different bending vibration of oxygen at tetrahedral units, and the other new peak at $558 \mathrm{~cm}^{-1}$ appeared at high pressure in the tetragonal phase because of the change of $\mathrm{O}-\mathrm{Mg}$-O bending from original higher-frequency $\mathrm{T}_{2 \mathrm{~g}}$. The cubic spinel $\mathrm{A}_{1 \mathrm{~g}}$ peak at $737 \mathrm{~cm}^{-1}$ split into two peaks at 809 and $836 \mathrm{~cm}^{-1}$, which can be attributed to differences in the shortening of bond lengths of the $\mathrm{MgO}_{4}$ tetrahedron. As a result, the observed Raman-mode frequencies $(\nu)$, pressure dependencies $\left(\mathrm{d} \nu_{\mathrm{i}} / \mathrm{d} P\right)$, and mode Grüneisen parameters $\left(\gamma_{\mathrm{i}}\right)$ for spinel and for the high-pressure phase are listed in Table 1. The pressure dependencies $\mathrm{d} \nu_{\mathrm{i}} / \mathrm{dP}_{\mathrm{P}} \mathrm{Mg}_{2} \mathrm{TiO}_{4}$ spinel indicate that two higher-frequency $\mathrm{T}_{2 \mathrm{~g}}$ and one $\mathrm{A}_{1 \mathrm{~g}}$ are more compressible, and the lowest-frequency $\mathrm{T}_{2 \mathrm{~g}}$ are stiffer. The lowest-frequency $\mathrm{E}_{\mathrm{g}}$ of the high-pressure phase is stiffer than the other Raman modes. Mode Grüneisen parameters $\left(\gamma_{\mathrm{i}}\right)$ are calculated from the equation $\gamma_{\mathrm{i}}=\frac{K_{\mathrm{T}}}{\nu_{0}}\left(\frac{\mathrm{d} \nu_{\mathrm{i}}}{\mathrm{d} P}\right)^{33}$, where isothermal bulk moduli $K_{\mathrm{T}}$ of spinel and tetragonal phase are both obtained from this study (see below). The thermal Grüneisen parameter $\left(\gamma_{\mathrm{th}}\right)^{34,35}$ can be calculated as the weighted average of the mode Grüneisen parameters $\left(\gamma_{\mathrm{i}}\right)$, which are listed in Table 1. The thermal Grüneisen parameter is given by $\gamma_{\mathrm{th}}=\frac{\Sigma_{i} C \mathrm{v}_{i} Y_{i}}{\Sigma_{i} C v_{i}}$, and the harmonic heat capacity $C \mathrm{v}_{i}$ was estimated from the Einstein function:

$$
\left.C \mathrm{v}_{i}=\kappa\left(\frac{h \nu_{i}}{\kappa T}\right)^{2} \exp \left(\frac{h \nu_{i}}{\kappa T}\right) / \exp \left(\frac{h \nu_{i}}{\kappa T}\right)-1\right]^{2}
$$




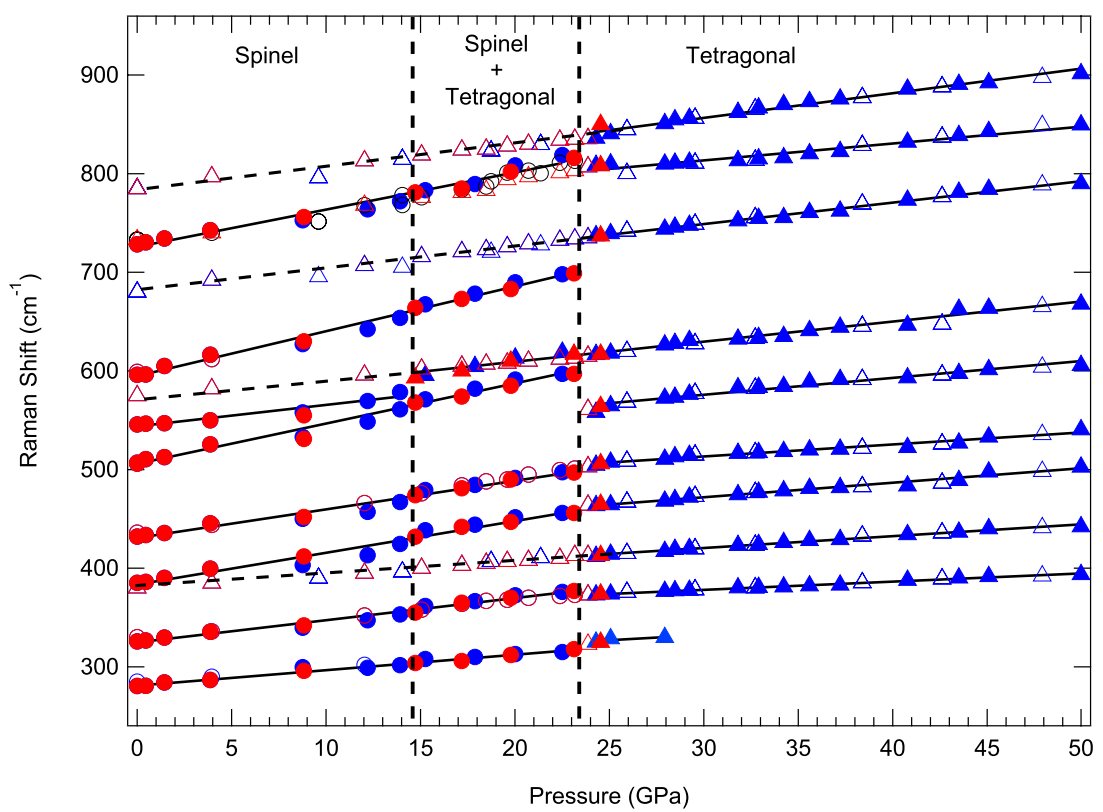

Figure 3. Raman frequency shifts as a function of pressure for $\mathrm{Mg}_{2} \mathrm{TiO}_{4}$ to $50.0 \mathrm{GPa}$. A new peak appears close to $595 \mathrm{~cm}^{-1}$ at $14.7 \mathrm{GPa}$ and four new Raman modes appear at $24.3 \mathrm{GPa}$. Solid symbols are compression data whereas the open symbols represent decompression. Circles denote spinel phase, and triangles the tetragonal phase. Red symbols denote the first run to $24.5 \mathrm{GPa}$ and blue symbols represent the second run to $50 \mathrm{GPa}$. The error bars of all data points are smaller than the symbols.

\begin{tabular}{|l|l|l|l|l|l|l|}
\hline \multicolumn{2}{|l}{ Spinel Phase } & \multicolumn{4}{l|}{ High-Pressure Phase } \\
\hline Mode & $\boldsymbol{\nu}\left(\mathbf{c m}^{-1}\right)$ & $\begin{array}{l}\mathbf{d} / \mathbf{d P} \\
\left(\mathbf{c m}^{-1} / \mathbf{G P a}\right)\end{array}$ & $\gamma_{\mathbf{i}}$ & $\boldsymbol{\nu}\left(\mathbf{c m}^{-1}\right)$ & $\begin{array}{l}\mathbf{d} / \mathbf{d P} \\
\left(\mathbf{c m}^{-1} / \mathbf{G P a}\right)\end{array}$ & $\gamma_{\mathbf{i}}$ \\
\hline $\mathrm{T}_{2 \mathrm{~g}}$ & 281 & 2.15 & 1.13 & 325 & 1.08 & 0.70 \\
\hline $\mathrm{E}_{\mathrm{g}}$ & 326 & 2.24 & 1.02 & 373 & 0.83 & 0.49 \\
\hline & & & & 413 & 1.20 & 0.65 \\
\hline $\mathrm{T}_{2 \mathrm{~g}}$ & 385 & 3.22 & 1.24 & 464 & 1.47 & 0.72 \\
\hline & 432 & 2.90 & 0.99 & 504 & 1.22 & 0.53 \\
\hline $\mathrm{T}_{2 \mathrm{~g}}$ & 506 & 4.08 & 1.19 & 558 & 1.71 & 0.68 \\
\hline & 546 & 2.17 & 0.59 & 617 & 2.04 & 0.75 \\
\hline $\mathrm{A}_{1 \mathrm{~g}}$ & 596 & 4.54 & 1.13 & 737 & 2.18 & 0.67 \\
\hline $\mathrm{A}_{\mathrm{lg}}$ & 728 & 3.77 & 0.77 & 809 & 1.71 & 0.47 \\
\hline & & & & 836 & 2.50 & 0.67 \\
\hline
\end{tabular}

Table 1. Observed Raman-mode frequencies $(\nu)$, pressure dependences $(\mathrm{d} \nu / \mathrm{dP})$, and calculated mode Grüneisen parameters $\left(\gamma_{\mathrm{i}}\right)$ for $\mathrm{Mg}_{2} \mathrm{TiO}_{4}$ at pressure to $50 \mathrm{GPa}$. The high-pressure tetragonal phase was collected from $24.3 \mathrm{GPa}$ to $50 \mathrm{GPa}$.

where temperature $T$ is 300 kelvins, $h$ is the Plank constant, and $\kappa$ is the Boltzmann constant. Our results show that the thermal Grüneisen parameter is 1.01 for the spinel phase and 0.63 for the tetragonal phase.

No $\mathrm{MgTiO}_{3}$ contaminant was observed during any of the X-ray diffraction measurements and the ambient-pressure unit-cell lattice parameters of synthetic $\mathrm{Mg}_{2} \mathrm{TiO}_{4}$ spinel collected at both $13-\mathrm{BM}-\mathrm{D}$ and 13-BM-C were confirmed to be the pure phase. The ambient-pressure unit-cell parameters of the synthetic $\mathrm{Mg}_{2} \mathrm{TiO}_{4}$ spinel are $\mathrm{a}_{0}=8.4464(2) \AA$ and $\mathrm{V}_{0}=602.59(5) \AA^{3}$, both of which are comparable with previous studies ${ }^{, 11,14,36}$. In-situ high-pressure X-ray diffraction patterns of $\mathrm{Mg}_{2} \mathrm{TiO}_{4}$ to $27.4 \mathrm{GPa}$ collected at beamline 13-BM-D (Run 1) are shown in Fig. 4a. Our two-dimensional images displayed a new feature at $15.7 \mathrm{GPa}$ which could be the high-pressure tetragonal phase T101 (Fig. 4b). At pressure above $22.8 \mathrm{GPa}$, additional new peaks were observed, allowing us to determine that the structure of the high-pressure phase is tetragonal I $4_{1} /$ amd (No. 141). Note that the spinel structure was found to coexist with this high-pressure tetragonal phase, but its diffraction peaks became weaker above $27.4 \mathrm{GPa}$. As a consequence, no further data at higher pressures were collected from Run 1 . Upon decompression, spinel and the tetragonal phases were found to coexist at all pressures to ambient conditions. For Run 2, the pressure was increased directly from 2.7 to $22 \mathrm{GPa}$ and then gradually compressed to $34 \mathrm{GPa}$ within 3 hours (Fig. 5a). Again, the high-pressure tetragonal phase coexisted with $\mathrm{Mg}_{2} \mathrm{TiO}_{4}$ spinel from 22 to $34 \mathrm{GPa}$ and the refined structure at $34 \mathrm{GPa}$ is shown in Fig. $5 \mathrm{c}$. However, the tetragonal phase T101 appeared at $32 \mathrm{GPa}$, which 
(a)

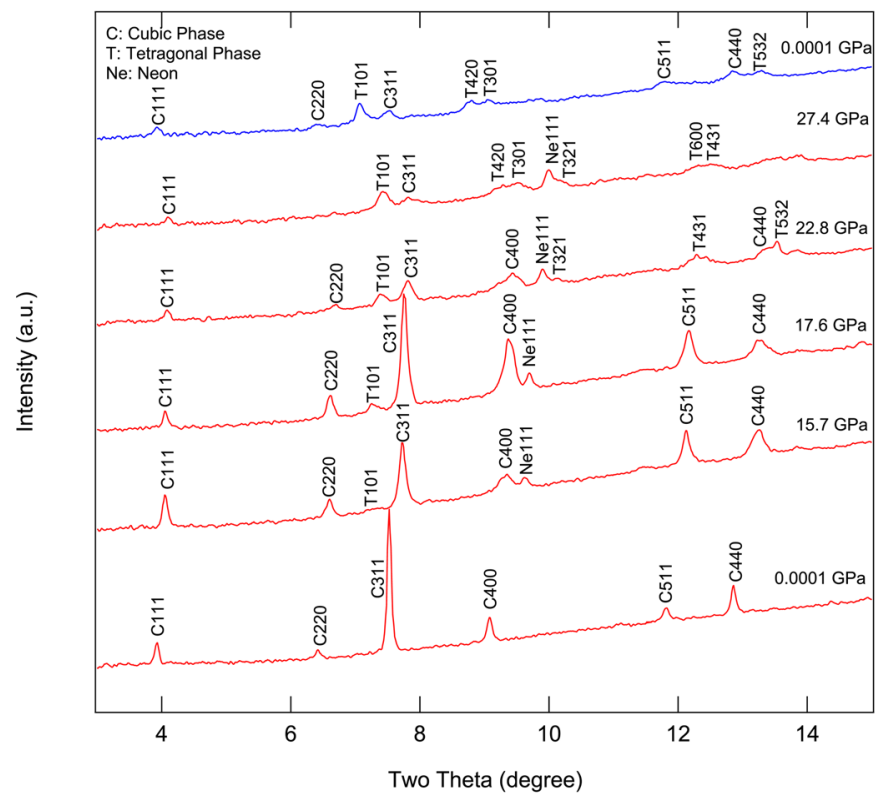

(b)

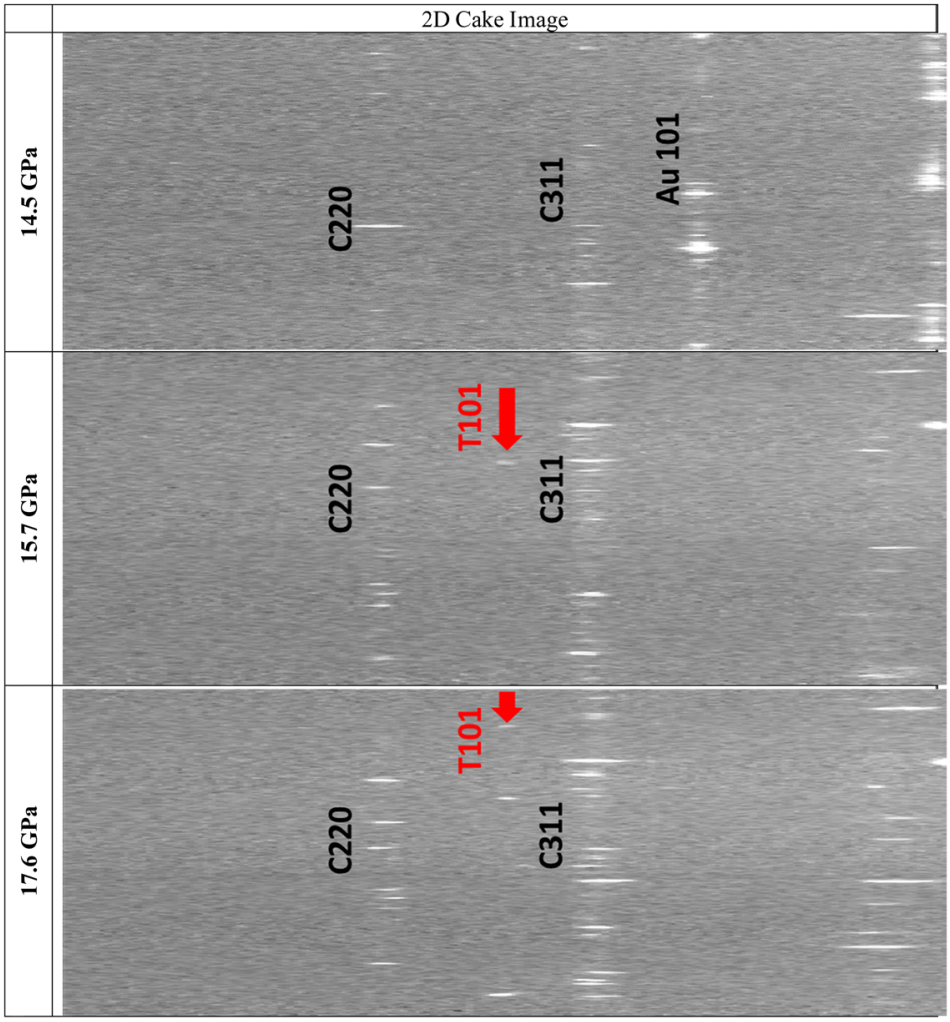

Figure 4. (a) Representative X-ray diffraction patterns of $\mathrm{Mg}_{2} \mathrm{TiO}_{4}$ collected in Run 1. A new peak 101 belongs to the high-pressure phase that coexisted with spinel from 15.7 to $27.4 \mathrm{GPa}$, and is also present in the decompressed pattern. Red; compression patterns, blue: decompression pattern. (b) 2D cake images show the new peak T101 observed above $15.7 \mathrm{GPa}$.

was about $18 \mathrm{GPa}$ higher than Run 1, and another new peak T220 appeared at $34 \mathrm{GPa}$ (Fig. 5b). For Run 3, the pressure was gently increased from 1 bar to $40.4 \mathrm{GPa}$ over 9 hours (Fig. 6). At $29.2 \mathrm{GPa}$ the cubic spinel had fully transformed to the tetragonal phase. After decompression, both spinel and high-pressure tetragonal phases were retained and persisted for at least $24 \mathrm{~h}$ after decompression to ambient conditions. The tetragonal phase T220 is critical for the structure determination but it is actually very weak. We checked all our $2 \mathrm{D}$ images and found the T220 only observable at $34 \mathrm{GPa}$ in Run 2 . In addition, for the tetragonal phase T532, it only can be assigned to the 

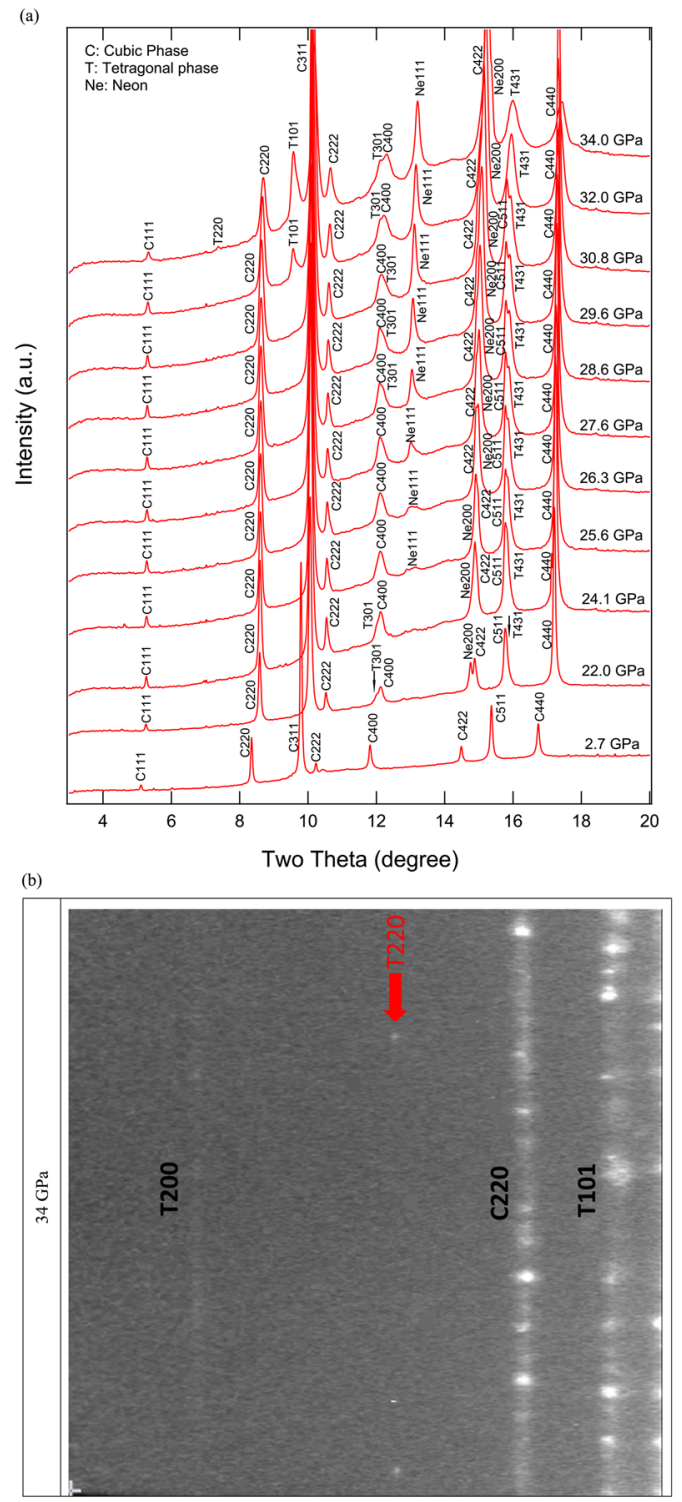

(c)

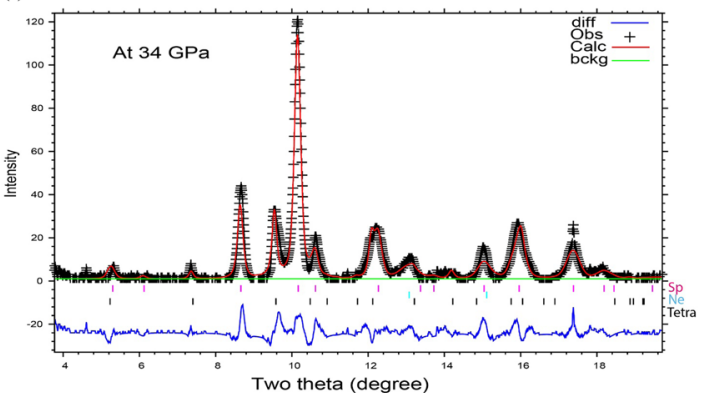

Figure 5. (a) Representative X-ray diffraction patterns of $\mathrm{Mg}_{2} \mathrm{TiO}_{4}$ collected in Run 2. The high-pressure tetragonal phase coexisted with low pressure phase at 22-34 GPa, but the T101 of high-pressure phase appeared from $32 \mathrm{GPa}$ and T220 appeared at $34 \mathrm{GPa}$. (b) $2 \mathrm{D}$ cake image showing the new T220 pattern at $34 \mathrm{GPa}$. (c) Le Bail refinement of X-ray diffraction pattern at $34 \mathrm{GPa}$. The ticks represent three calculated structures: Tetra high-pressure tetrahedral phase, $\mathrm{Sp}$ - ambient pressure cubic phase and $\mathrm{Ne}$ - pressure medium.

tetragonal phase by doubling the c-axis to $5.446 \AA$ at $25.9 \mathrm{GPa}$ in Run 3. In summary, our X-ray diffraction results suggest that the tetragonal phase transformation started at $15.7 \mathrm{GPa}$ and completed at $29.2 \mathrm{GPa}$. In addition, in all three runs, the coexistences of spinel and tetragonal phases over variable ranges of pressure are likely to be a result of sluggish kinetics. Our X-ray diffraction data showed both spinel and tetragonal phases were present between 


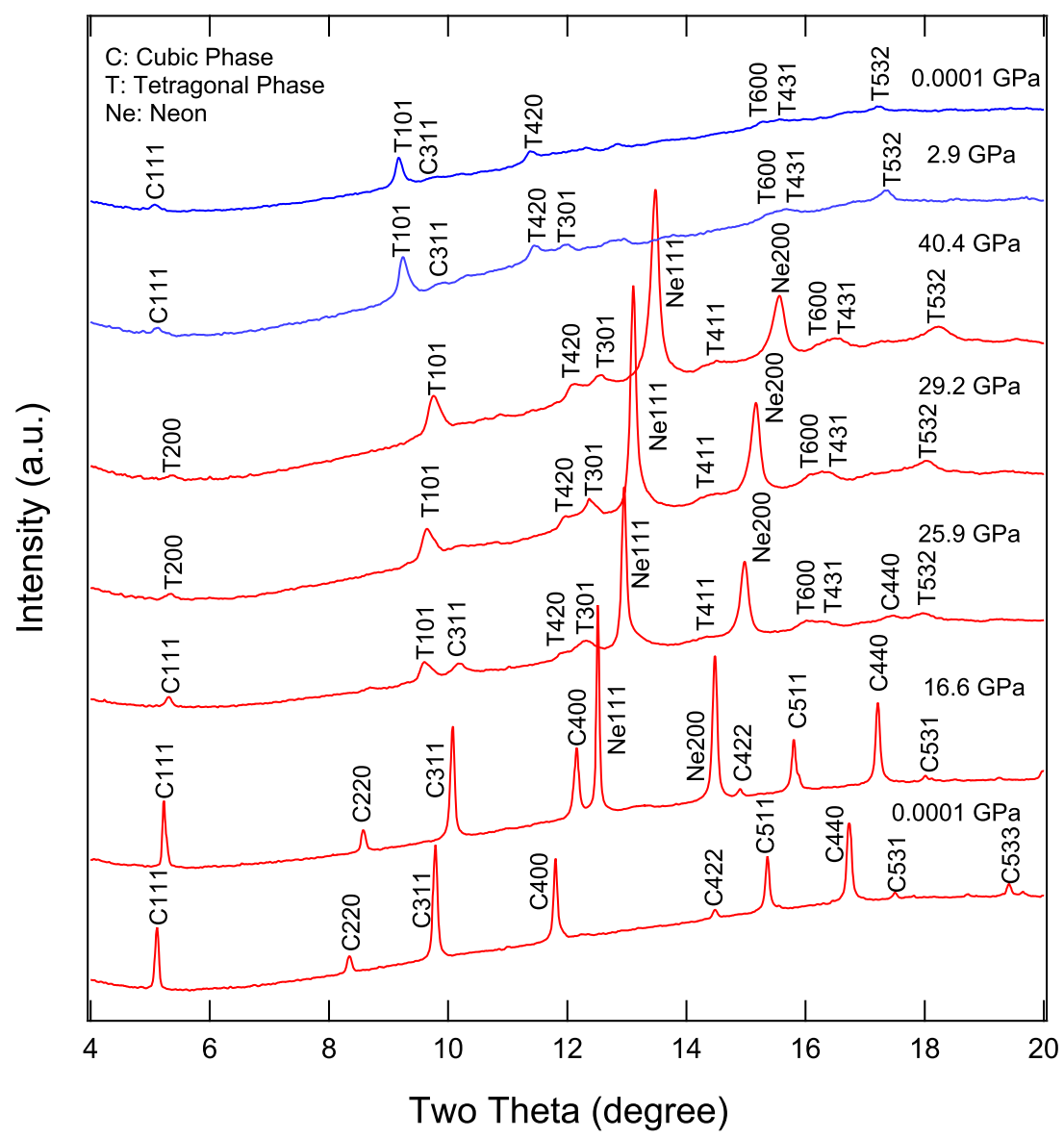

Figure 6. Representative X-ray diffraction patterns of $\mathrm{Mg}_{2} \mathrm{TiO}_{4}$ collected in Run 3. Cubic $\mathrm{Mg}_{2} \mathrm{TiO}_{4}$ spinel fully transforms to tetragonal structure at $29.2 \mathrm{GPa}$. Upon decompression, both low- and high-pressure phases were present at ambient pressure. The room-pressure pattern was collected after 24 hours of decompression. (Red: compression patterns; blue: decompression patterns).

\begin{tabular}{|l|l|l|l|l|l|l|}
\hline \multicolumn{9}{|l|}{ Spinel Structure } & \multicolumn{5}{l|}{ Tetragonal Structure } \\
\hline $\mathbf{P}(\mathbf{G P a})$ & $\mathbf{a}(\AA)$ & $\mathbf{V}\left(\AA^{3}\right)$ & $\mathbf{P}(\mathbf{G P a})$ & $\mathbf{a}(\AA)$ & $\mathbf{c}(\AA)$ & $\mathbf{V}\left(\AA^{3}\right)$ \\
\hline 0.0001 & $8.4464(3)$ & $602.59(5)$ & $25.1(1)$ & $9.4686(5)$ & $2.7233(3)$ & $244.16(4)$ \\
\hline $0.4(1)$ & $8.4366(2)$ & $600.49(5)$ & $25.9(1)$ & $9.4598(5)$ & $2.7228(3)$ & $243.65(4)$ \\
\hline $1.6(1)$ & $8.4137(2)$ & $595.62(5)$ & $27.4(1)$ & $9.4410(5)$ & $2.7216(3)$ & $242.58(4)$ \\
\hline $2.7(1)$ & $8.3935(2)$ & $591.33(5)$ & $28.5(1)$ & $9.4282(5)$ & $2.7208(3)$ & $241.85(4)$ \\
\hline $4.4(1)$ & $8.3684(2)$ & $586.04(5)$ & $29.2(1)$ & $9.4192(5)$ & $2.7202(3)$ & $241.34(4)$ \\
\hline $5.7(1)$ & $8.3447(2)$ & $581.08(5)$ & $30.3(1)$ & $9.4062(5)$ & $2.7194(3)$ & $240.60(4)$ \\
\hline $7.0(1)$ & $8.3293(2)$ & $577.87(5)$ & $31.5(1)$ & $9.3923(5)$ & $2.7185(3)$ & $239.81(4)$ \\
\hline $7.9(1)$ & $8.3146(1)$ & $574.81(5)$ & $32.9(1)$ & $9.3753(5)$ & $2.7174(3)$ & $238.85(4)$ \\
\hline $9.3(1)$ & $8.3024(1)$ & $571.94(5)$ & $33.9(1)$ & $9.3632(5)$ & $2.7166(3)$ & $238.17(4)$ \\
\hline $10.1(1)$ & $8.2871(1)$ & $569.12(5)$ & $34.8(1)$ & $9.3521(5)$ & $2.7159(3)$ & $237.54(4)$ \\
\hline $11.1(1)$ & $8.2670(2)$ & $564.99(5)$ & $36.1(1)$ & $9.3369(5)$ & $2.7150(3)$ & $236.68(4)$ \\
\hline $12.1(1)$ & $8.2629(2)$ & $564.15(5)$ & $37.4(1)$ & $9.3217(5)$ & $2.7140(3)$ & $235.83(4)$ \\
\hline $13.0(1)$ & $8.2530(2)$ & $562.13(5)$ & $38.7(1)$ & $9.3055(5)$ & $2.7130(3)$ & $234.92(4)$ \\
\hline $14.4(1)$ & $8.2364(2)$ & $558.74(5)$ & $40.4(1)$ & $9.2851(5)$ & $2.7117(3)$ & $233.79(4)$ \\
\hline $15.7(1)$ & $8.2154(2)$ & $554.48(5)$ & & & & \\
\hline $17.6(1)$ & $8.1987(2)$ & $551.10(5)$ & & & & \\
\hline
\end{tabular}

Table 2. Unit-cell lattice parameters of $\mathrm{Mg}_{2} \mathrm{TiO}_{4}$ for spinel and tetragonal phase obtained at high pressures. Numbers within parenthesis showed uncertainty of the last digit 


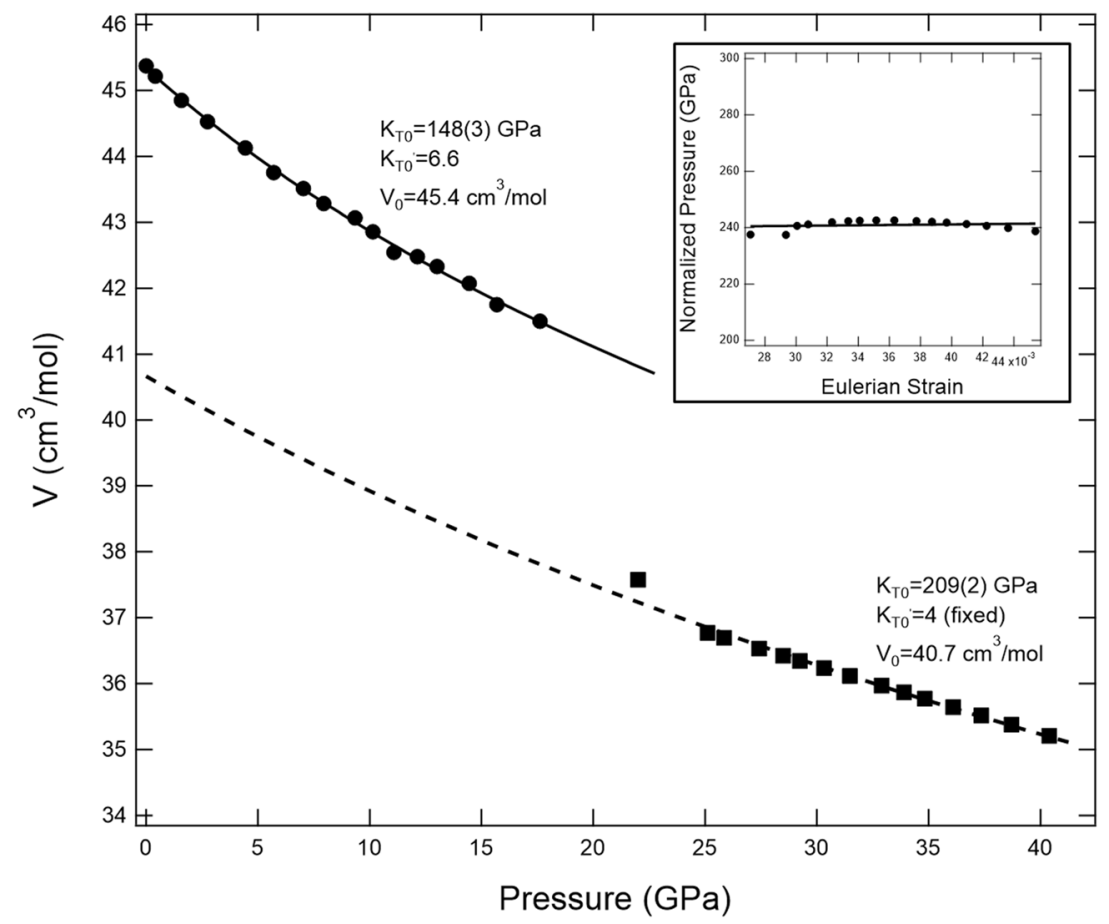

Figure 7. The molar volume as a function of pressure for $\mathrm{Mg}_{2} \mathrm{TiO}_{4}$ to $40 \mathrm{GPa}$. Solid circles represent volumes of cubic phase and solid squares are from high-pressure tetragonal phase. The solid and dashed curves are best-fit third-order Birch-Murnaghan equations of state. The error bars of all data points are smaller than the symbols. The Eulerian strain-normalized pressure plot shows that $K_{\mathrm{TO}}$ ' of the high-pressure phase is close to 4 .

\begin{tabular}{|l|l|l|l|l|l|l|l|l|}
\hline Compound & $\mathbf{r}_{\mathbf{a}}(\boldsymbol{\AA})$ & $\mathbf{r}_{\mathbf{b}}(\boldsymbol{\AA})$ & $\mathbf{V}\left(\AA^{3}\right)$ & $\mathbf{a}(\boldsymbol{\AA})$ & $\mathbf{K}_{\mathbf{0}}(\mathbf{G P a})$ & $\mathbf{K}_{\mathbf{0}}{ }^{\prime}$ & HP Phase & Reference \\
\hline $\mathrm{FeCr}_{2} \mathrm{O}_{4}$ & 0.78 & 0.615 & 588 & 8.378 & 209 & 4.0 & $\mathrm{I} 4_{1} / \mathrm{amd}$ & ${ }^{21}$ \\
\hline $\mathrm{Fe}_{3} \mathrm{O}_{4}$ & 0.78 & 0.645 & 591.4 & 8.394 & 182 & 3.6 & $P b c m$ & 54 \\
\hline $\mathrm{Fe}_{2} \mathrm{TiO}_{4}$ & 0.605 & 0.645 & 624.3 & 8.530 & 250.8 & 4.0 & $\mathrm{Cmcm}$ & 38 \\
\hline $\mathrm{MgAl}_{2} \mathrm{O}_{4}$ & 0.72 & 0.535 & 507.8 & 7.978 & 212 & 6.3 & $P n m a$ & 55 \\
\hline $\mathrm{MgCr}_{2} \mathrm{O}_{4}$ & 0.72 & 0.615 & 578.7 & 8.333 & 189 & 7.2 & $\mathrm{I} 4_{1} / \mathrm{amd}$ & 22 \\
\hline $\mathrm{Mg}_{2} \mathrm{TiO}_{4}$ & 0.605 & 0.72 & 602.6 & 8.446 & 166 & 4 & $\mathrm{I} 4_{1} / \mathrm{amd}$ & This Study \\
\hline $\mathrm{MgFe}_{2} \mathrm{O}_{4}$ & 0.72 & 0.645 & 589.9 & 8.387 & 195 & 4 & $P b c m$ & 40 \\
\hline $\mathrm{MnFe}_{2} \mathrm{O}_{4}$ & 0.83 & 0.645 & 617.5 & 8.5157 & 169.7 & 2.87 & $P b c m$ & 42 \\
\hline $\mathrm{NiMn}_{2} \mathrm{O}_{4}$ & 0.69 & 0.645 & 590.6 & 8.390 & 206 & 4 & $\mathrm{I} 4_{1} / \mathrm{amd}$ & 45 \\
\hline $\mathrm{ZnAl}_{2} \mathrm{O}_{4}$ & 0.74 & 0.535 & 529.7 & 8.091 & 201.7 & 7.62 & $P n m a$ & 56 \\
\hline $\mathrm{ZnGa}_{2} \mathrm{O}_{4}$ & 0.74 & 0.62 & 580.1 & 8.340 & 233 & 8.3 & $\mathrm{I} 4_{1} / \mathrm{amd}$ & 57 \\
\hline $\mathrm{Zn}_{2} \mathrm{TiO}_{4}$ & 0.605 & 0.74 & 608.2 & 8.472 & 154.6 & 4 & $\mathrm{I} 4_{1} / \mathrm{amd}$ & 48 \\
\hline $\mathrm{Co}_{2} \mathrm{TiO}_{4}$ & 0.605 & 0.75 & 604.38 & 8.454 & 167.2 & 4 & $P b c m$ & 58 \\
\hline
\end{tabular}

Table 3. Comparison of the radii of cations, volumes, unit-cell parameters, and bulk moduli of different spinels.

15.7 and 29.2 GPa, but in the Raman measurements the mixture of phases is limited to a smaller pressure range. We postulate that this is owing to longer collection time in Raman measurements than in the X-ray diffraction measurements and perhaps because local atomic bonding distortions and variations detected by Raman scattering are more sensitive than the bulk structural changes measured using the X-ray diffraction method.

The unit-cell lattice parameters and volume data of $\mathrm{Mg}_{2} \mathrm{TiO}_{4}$ at pressure to $40.4 \mathrm{GPa}$ are summarized in Table 3. The $\mathrm{Mg}_{2} \mathrm{TiO}_{4}$ volume data with respect to pressures were fitted with a third-order Birch-Murnaghan equation of state, with all volume data expressed as molar volumes (Fig. 7). The obtained isothermal bulk modulus of $\mathrm{Mg}_{2} \mathrm{TiO}_{4}$ spinel is $K_{\mathrm{T} 0}=148(3) \mathrm{GPa}$ when $K_{\mathrm{T} 0}{ }^{\prime}=6.6$, and $K_{\mathrm{T} 0}=166(1) \mathrm{GPa}$ when $K_{\mathrm{T} 0}$ ' is fixed at 4 , in agreement with previous studies ${ }^{13,14}$. The volume change between spinel and tetragonal phase is about $9 \%$. The unit-cell lattice parameters of tetragonal phase obtained from this study are also listed in Table 2 . The bulk modulus $K_{\mathrm{T} 0}$ of the tetragonal phase is obtained as $209(2) \mathrm{GPa}$ and $\mathrm{V}_{0}=270(2) \AA^{3}$ when $K_{\mathrm{T} 0}$ ' is fixed at 4 , based on the trend of Eulerian strain-normalized pressure plot $^{37}$.

To evaluate the post-spinel structure for the orthotitanates, we compare several spinel phases and their post-spinel structures such as $\mathrm{CT}^{38}, \mathrm{CM}^{39-42}, \mathrm{CF}^{20,41,43,44}$, and intermediate phases ${ }^{20-23,45,46}$ (Table 3 ). The CF phase of $\mathrm{AB}_{2} \mathrm{O}_{4}$ post-spinel was limited by the radius ratio $\mathrm{r}_{\mathrm{B}} / \mathrm{r}_{\mathrm{A}}$. In general, $\mathrm{CF}$ phase can be found in the range of 0.53 to 


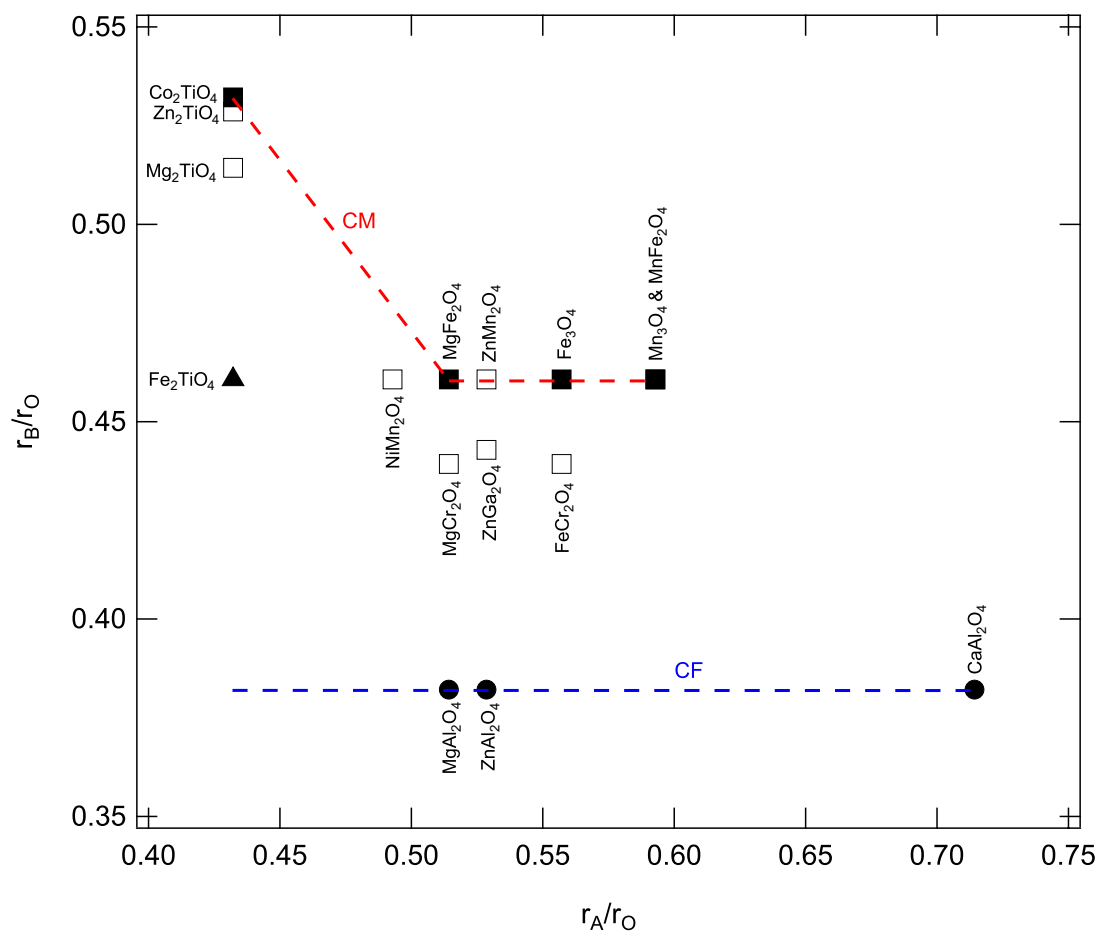

Figure 8. The radius ratio $r_{A} / r_{O}$ versus $r_{B} / r_{O}$. for different spinels. Four different post-spinel structures, CT (solid triangle), CF (solid circle), tetragonal (open square), and CM (solid square), are shown. There are two curves which show the trends of CM (red) and CF (blue) post-spinel phases, respectively. The trend of CF at lower $\mathrm{r}_{\mathrm{A}} / \mathrm{r}_{\mathrm{O}}$ is calculated from ${ }^{47}$. Different post-spinel phases lie in the small region of $\mathrm{r}_{\mathrm{A}} / \mathrm{r}_{\mathrm{O}}<0.45$ and $\mathrm{r}_{\mathrm{B}} /$ $\mathrm{r}_{\mathrm{O}}>0.5$. The regions of CM and tetragonal are quite close, but the trends between CM and CF are distinct.

0.89 , but not in the case of $\mathrm{r}_{\mathrm{B}} / \mathrm{r}_{\mathrm{A}}<0.53^{47}$. The radius ratio $\mathrm{r}_{\mathrm{B}} / \mathrm{r}_{\mathrm{A}}$ of $\mathrm{Mg}_{2} \mathrm{TiO}_{4}$ is around 1.19 which is larger than the range of CF phase but very close to $\mathrm{Zn}_{2} \mathrm{TiO}_{4}$ with radius ratio $r_{\mathrm{B}} / \mathrm{r}_{\mathrm{A}}$ of 1.22 . The post-spinel structure of $\mathrm{Zn}_{2} \mathrm{TiO}_{4}$ was suggested to be CT phase ${ }^{48}$ with an intermediate tetragonal phase ${ }^{23}$. The radii of cations ${ }^{49}$ in tetrahedral and octahedral sites could be a determining factor in the structure of $\mathrm{AB}_{2} \mathrm{O}_{4}$ spinel. Normal spinel has the formula $\mathrm{A}^{\mathrm{T}} \mathrm{B}_{2}^{\mathrm{O}} \mathrm{O}_{4}$, where $\mathrm{A}$ cations sit in tetrahedral sites and $\mathrm{B}$ cations sit in octahedral ones. If the radius of $\mathrm{A}$ cations is too big, they are unlikely to remain in tetrahedral sites. The formula of inverse spinel can be expressed as $\mathrm{B}^{\mathrm{T}}(\mathrm{A}, \mathrm{B})^{\mathrm{O}} \mathrm{O}_{4}$, where A cations do not sit in tetrahedral sites anymore and the size limit for $\mathrm{B}$ cations is smaller as they have to fit into tetrahedral sites. Nevertheless, whether in normal or inverse spinels, A cations are usually larger than B cations under ambient conditions. Figure 8 shows the radius ratio $r_{A} / r_{O}$ with respect to $r_{B} / r_{O}$ for several different spinels at ambient conditions, and two distinct trends of $\mathrm{CM}$ and $\mathrm{CF}$ are observed. Intermediate tetragonal and CT phases lie mostly between CM and CF curves. The A cations $\left(\mathrm{Ti}^{4+}\right)$ of $\mathrm{Mg}_{2} \mathrm{TiO}_{4}, \mathrm{Zn}_{2} \mathrm{TiO}_{4}$, and $\mathrm{Co}_{2} \mathrm{TiO}_{4}$ inverse spinels are the same and the radii of $\mathrm{B}$ cations $\left(\mathrm{Mg}^{2+}, \mathrm{Zn}^{2+}\right.$, and $\left.\mathrm{Co}^{2+}\right)$ are very similar. However, they have different post-spinel structures within the area $r_{A} / r_{O}<0.45$ and $r_{B} / r_{O}>0.5$. The possible explanation is that when $r_{A}$ is smaller than $r_{B}$, not only $\mathrm{B}$ cations can sit in both tetrahedron and octahedron but also A cations. With the exception of the CF phase, the trends of all post spinels are located within the area where radius ratio $\mathrm{r}_{\mathrm{B}} / \mathrm{r}_{\mathrm{A}}$ is smaller than 1 .

\section{Conclusion}

Two sets of Raman measurements were performed at pressure to $24.5 \mathrm{GPa}$ and $50 \mathrm{GPa}$ in this study. Our Raman results demonstrated that a phase transformation occurred at $14.7 \mathrm{GPa}$, and a two-phase mixture persisted at pressure up to $24.3 \mathrm{GPa}$. The cubic $\mathrm{Mg}_{2} \mathrm{TiO}_{4}$ spinel fully transformed to a tetragonal phase above $24.3 \mathrm{GPa}$ and the new phase persisted to $50 \mathrm{GPa}$. On decompression, the high-pressure phase was observable from 50 to about 18.7 GPa, and most Raman features were diminished with further decompression except the broad $\mathrm{A}_{1 \mathrm{~g}}$ peak near $700-800 \mathrm{~cm}^{-1}$. The high-pressure phase was partly quenchable below $18.7 \mathrm{GPa}$, and both spinel and high-pressure phases coexisted to ambient pressure. Our X-ray diffraction data suggest that the tetragonal phase transformation started at $15.7 \mathrm{GPa}$ and completed at 29.2 GPa. The coexisting cubic and tetragonal phases are also shown on our decompression X-ray diffraction patterns at ambient pressure. Comparing our three X-ray diffraction runs, the coexistence of spinel and tetragonal phases extends over three different pressure ranges, and the full phase transformation pressure is $\sim 5 \mathrm{GPa}$ higher than Raman measurements, which is likely the result of slow kinetics. The obtained isothermal bulk modulus of $\mathrm{Mg}_{2} \mathrm{TiO}_{4}$ spinel is $K_{\mathrm{T} 0}=148(3) \mathrm{GPa}$ when $K_{\mathrm{T} 0}{ }^{\prime}=6.6$, or $K_{\mathrm{T} 0}=166(1) \mathrm{GPa}$ when $K_{\mathrm{T} 0}$ ' is fixed at 4 . The isothermal bulk modulus of high-pressure tetragonal phase is calculated as $209(2) \mathrm{GPa}$ and $\mathrm{V}_{0}=270(2) \AA^{3}$ when $K_{\mathrm{TO}}$ ' is fixed at 4 , and the volume reduction from cubic to tetragonal phase is about $9 \%$. Grüneisen parameters $\left(\gamma_{t h}\right)$ calculated from the isothermal bulk moduli $K_{\mathrm{T}}$ of spinel and tetragonal phases obtained from this study are 1.01 and 0.63 . A simple model to predict post-spinel structures is proposed based on the radii ratio of spinel cations and our model shows the tetragonal phases located in between the CF and CM trends. 


\section{Experimental Methods}

In situ high-pressure and room-temperature Raman and X-ray diffraction measurements on $\mathrm{Mg}_{2} \mathrm{TiO}_{4}$ qandilite were performed at pressure to 50 and $40.4 \mathrm{GPa}$, respectively, using symmetric diamond anvil cells. $\mathrm{Mg}_{2} \mathrm{TiO}_{4}$ qandilite starting material was synthesized at $1673 \mathrm{~K}$ for $52 \mathrm{~h}$ from a mixture of $\mathrm{MgO}$ and $\mathrm{TiO}_{2}$. The product was examined by electron probe microanalysis and conventional X-ray diffraction. The results show $\mathrm{Mg}_{2} \mathrm{TiO}_{4}$ with less than $5 \%$ of $\mathrm{MgTiO}_{3}{ }^{14}$. We used a pair of $300-\mu \mathrm{m}$ diamond culets for both Raman and X-ray diffraction measurements in the high-pressure diamond anvil cell study. Rhenium gaskets were pre-indented to $35-40 \mu \mathrm{m}$ thickness and a $150-\mu \mathrm{m}$ hole was drilled to create a sample chamber. Neon was used as a pressure-transmitting medium, together with 1 or 2 ruby spheres for both Raman and X-ray diffraction experiments. A small piece of $10-15 \mu \mathrm{m}$ gold foil was also loaded in the sample chamber as a pressure marker for the synchrotron X-ray study. Pressure was monitored by the ruby fluorescence method ${ }^{50}$ and/or equation of state of gold ${ }^{51}$.

Raman spectra were collected at the University of Western Ontario using a custom-built system. An argon-ion laser with a wavelength of $514.5 \mathrm{~nm}$ was used as an excitation source. The Raman signals were collected by a spectrometer with a 500-mm focal length and equipped with a liquid nitrogen-cooled CCD detector. The spectrometer was calibrated by a neon lamp and a silicon chip. The uncertainty in Raman shift measurements did not exceed $1 \mathrm{~cm}^{-1}$. Two different in situ Raman measurements were carried out to 24.5 and $50 \mathrm{GPa}$, respectively. The pressure was measured by the shift of ruby $\mathrm{R}_{1}$ emission peak before and after Raman measurements. The collection time of each spectrum was 240 seconds at lower pressure and then increased to 420 seconds at pressure above $24 \mathrm{GPa}$. The reported spectrum was the average of five spectra at each pressure step. Peakfit software (SPSS Inc., Chicago) was used for Raman peak curve-fitting.

In situ high-pressure angular-dispersive $\mathrm{X}$-ray diffraction experiments were carried out at beamline 13-BM-C and 13-BM-D, sectors of GSECARS, Advanced Photon Source. At both beamlines $\mathrm{LaB}_{6}$ was used for sample-to-detector distance calibration. The purity of the $\mathrm{Mg}_{2} \mathrm{TiO}_{4}$ spinel phase was confirmed by X-ray diffraction before the high-pressure experiments. One run (Run 1) at pressure to 27.4 GPa was performed at 13-BM-D. The wavelength of the monochromatic X-ray beam at $13-\mathrm{BM}-\mathrm{D}$ was $0.3344 \AA$, and the beam size was focused to $3 \times 7 \mu \mathrm{m}$. Two runs (Run 2 and 3 ) at pressures to 34 and $40.4 \mathrm{GPa}$ were conducted at 13-BM-C. The wavelength of the monochromatic X-ray beam at $13-\mathrm{BM}-\mathrm{C}$ was $0.434 \AA$ and beam size was focused to $12 \times 18 \mu \mathrm{m}$. $\mathrm{X}$-ray diffraction patterns were collected by two-dimensional MAR CCD at 13-BM-C and the exposure time of each pattern was 90-120 seconds with sample rotation angle from 80 to 100 degrees. The exposure time of a Perkin-Elmer area detector for each collection at 13-BM-D was 5 seconds without rotation and each diffraction image was the average of 20 patterns to enhance the signal-to-noise ratio. Two-dimensional images were integrated and reduced to one-dimensional patterns using Dioptas software ${ }^{52}$. The powder X-ray diffraction data were processed using the software PeakFit V4.12 (SPSS Inc.) and the unit cell parameters were calculated by the program UnitCell ${ }^{53}$. Experimental powder diffraction results are compared to theoretical values calculated using CRYSTALDIFFRACT software and Le Bail refinement by GSAS (Fig. 5c).

Received: 26 June 2019; Accepted: 20 March 2020;

Published online: 14 April 2020

\section{References}

1. Bhuyan, R., Santhosh Kumar, T., Perumal, A., Ravi, S. \& Pamu, D. Optical properties of ambient temperature grown nanocrystalline $\mathrm{Mg}_{2} \mathrm{TiO}_{4}$ thin films. Surf. Coatings Technol. 221, 196-200 (2013).

2. Cheng, L., Liu, P., Qu, S., Cheng, L. \& Zhang, H. Microwave dielectric properties of $\mathrm{Mg}_{2} \mathrm{TiO}_{4}$ ceramics synthesized via high energy ball milling method. J. Alloys Compd. 623, 238-242 (2015).

3. Haefke, H. et al. $\mathrm{Mg}_{2} \mathrm{TiO}_{4}$ as a novel substrate for high-temperature superconducting thin films. Applied Physics Letters 61, 2359-2361 (1992).

4. Zeng, J., Wang, H., Shang, S., Wang, Z. \& Lin, C. Preparation of textured $\mathrm{Mg}_{2} \mathrm{TiO}_{4}$ thin films on Si substrate by atmospheric pressure metallorganic chemical vapour deposition. J. Mater. Sci. Mater. Electron. 8, 159-162 (1997).

5. Ho, Y., Su, C. \& Huang, C. Intense red photoluminescence emission of sol-gel-derived nanocrystalline $\mathrm{Mg}_{2} \mathrm{TiO}_{4}$ thin films. J. Am. Ceram. Soc. 97, 358-360 (2014).

6. Gittins, J., Fawcett, J. \& Rucklidge, J. An occurrence of the spinel end-member $\mathrm{Mg}_{2} \mathrm{TiO}_{4}$ and related spinel solid solutions. Mineral. Mag. 45, 135-137 (1982).

7. Al-Hermezi, H. Qandilite, a new spinel end-member, $\mathrm{Mg}_{2} \mathrm{TiO}_{4}$, from the Qala-Dizeh region, NE Iraq. Mineral. Mag. 49, 739-744 (1985).

8. Wechsler, B. \& Navrotsky, A. Thermodynamics and structural chemistry of compounds in the system $\mathrm{MgO}-\mathrm{TiO}_{2}$. J. Solid State Chem. 55, 165-180 (1984).

9. Millard, R., Peterson, R. \& Hunter, B. Study of the cubic to tetragonal transition in $\mathrm{Mg}_{2} \mathrm{TiO}_{4}$ and $\mathrm{Zn}_{2} \mathrm{TiO}_{4}$ spinels by ${ }^{17} \mathrm{O}$ NMR and Rietveld refinement of X-ray diffraction data. Am. Mineral. 80, 885-896 (1995).

10. Akimoto, S. \& Syono, Y. High-pressure decomposition of some titanate spinels. J. Chem. Phys. 47, 1813-1817 (1967).

11. O'Neill, H., Redfern, S., Kesson, S. \& Short, S. An in situ neutron diffraction study of cation disordering in synthetic qandilite $\mathrm{Mg}_{2} \mathrm{TiO}_{4}$ at high temperatures. Am. Mineral. 88, 860-865 (2003).

12. Kumar, S. et al. Structural and electrical properties of $\mathrm{Mg}_{2} \mathrm{TiO}_{4}$. J. Ceram. Soc. Japan 117, 689-692 (2009).

13. Hazen, R. \& Yang, H. Effects of cation substitution and order-disorder on P-V-T equations of state of cubic spinels. Am. Mineral. 84, 1956-1960 (1999).

14. Lv, M. et al. Equation of state of synthetic qandilite $\mathrm{Mg}_{2} \mathrm{TiO}_{4}$ at ambient temperature. Phys. Chem. Miner. 43, 301-306 (2016).

15. Liebermann, R., Jackson, I. \& Ringwood, A. Elasticity and phase-equilibria of spinel disproportionation reactions. Geophys. J. R. Astron. Soc. 50, 553-586 (1977).

16. Yamanaka, T., Uchida, A. \& Nakamoto, Y. Structural transition of post-spinel phases $\mathrm{CaMn}_{2} \mathrm{O}_{4}, \mathrm{CaFe}_{2} \mathrm{O}_{4}$, and CaTi $\mathrm{O}_{4}$ under high pressures up to $80 \mathrm{GPa}$. Am. Mineral. 93, 1874-1881 (2008).

17. Chen, M., Shu, J., Mao, H., Xie, X. \& Hemley, R. J. Natural occurrence and synthesis of two new postspinel polymorphs of chromite. Proc. Natl. Acad. Sci. 100, 14651-14654 (2003).

18. Ishii, T. et al. High-pressure phase transitions in $\mathrm{FeCr}_{2} \mathrm{O}_{4}$ and structure analysis of new post-spinel $\mathrm{FeCr}_{2} \mathrm{O}_{4}$ and $\mathrm{Fe}_{2} \mathrm{Cr}_{2} \mathrm{O}_{5}$ phases with meteoritical and petrological implications. Am. Mineral. 99, 1788-1797 (2014). 
19. Ishii, T. et al. High-pressure high-temperature transitions in $\mathrm{MgCr}_{2} \mathrm{O}_{4}$ and crystal structures of new $\mathrm{Mg}_{2} \mathrm{Cr}_{2} \mathrm{O}_{5}$ and post-spinel $\mathrm{MgCr}_{2} \mathrm{O}_{4}$ phases with implications for ultrahigh-pressure chromitites in ophiolites. Am. Mineral. 100, 59-65 (2015).

20. López-Moreno, S. et al. Lattice dynamics of $\mathrm{ZnAl}_{2} \mathrm{O}_{4}$ and $\mathrm{ZnGa}_{2} \mathrm{O}_{4}$ under high pressure. Ann. der Phys. 523, 157-167 (2011).

21. Kyono, A. et al. The influence of the Jahn-Teller effect at $\mathrm{Fe}^{2+}$ on the structure of chromite at high pressure. Phys. Chem. Miner. 39, 131-141 (2012).

22. Yong, W., Botis, S., Shieh, S., Shi, W. \& Withers, A. C. Pressure-induced phase transition study of magnesiochromite $\left(\mathrm{MgCr}_{2} \mathrm{O}_{4}\right)$ by Raman spectroscopy and X-ray diffraction. Phys. Earth Planet. Inter. 196-197, 75-82 (2012).

23. Wang, Z., Saxena, S. \& Zha, C. In situ $\mathrm{x}$-ray diffraction and Raman spectroscopy of pressure-induced phase transformation in spinel $\mathrm{Zn}_{2} \mathrm{TiO}_{4}$. Phys. Rev. B 66, 024103 (2002)

24. Darul, J., Lathe, C. \& Piszora, P. $\mathrm{Mn}_{3} \mathrm{O}_{4}$ under high pressure and temperature: Thermal stability, polymorphism, and elastic properties. J. Phys. Chem. C 117, 23487-23494 (2013).

25. Lv, H. et al. Effect of grain size on pressure-induced structural transition in $\mathrm{Mn}_{3} \mathrm{O}_{4}$. J. Phys. Chem. C 116, 2165-2171 (2012).

26. Frost, D. The Upper Mantle and Transition Zone. Elements 4, 171-176 (2008).

27. White, W. \& DeAngelis, B. Interpretation of the vibrational spectra of spinels. Spectrochim. Acta Part A Mol. Spectrosc. 23, 985-995 (1967).

28. Cynn, H., Sharma, S., Cooney, T. \& Nicol, M. High-temperature Raman investigation of order-disorder behavior in the $\mathrm{MgAl}_{2} \mathrm{O}_{4}$ spinel. Phys. Rev. B 45, 500-502 (1992).

29. deWijs, G., Fang, C., Kresse, G. \& deWith, G. First-principles calculation of the phonon spectrum of $\mathrm{MnAl}_{2} \mathrm{O}_{4}$ spinel. Phys. Rev. B 65, 094305 (2002).

30. Chandramohan, P., Srinivasan, M., Velmurugan, S. \& Narasimhan, S. Cation distribution and particle size effect on Raman spectrum of $\mathrm{CoFe}_{2} \mathrm{O}_{4}$. J. Solid State Chem. 184, 89-96 (2011).

31. O’Horo, M., Frisillo, A. \& White, W. Lattice vibrations of $\mathrm{MgAl}_{2} \mathrm{O}_{4}$ spinel. J. Phys. Chem. Solids 34, 23-28 (1973).

32. Reynard, B. \& Guyot, F. High-temperature properties of geikielite $\left(\mathrm{MgTiO}_{3}\right.$-Ilmenite) from high-temperature high-pressure Raman spectroscopy- some implications for $\mathrm{MgSiO}_{3}$-ilmenite. Phys. Chem. Miner. 21, 441-450 (1994).

33. Gillet, P., Guyot, F. \& Malezieux, J. High-pressure, high-temperature Raman spectroscopy of $\mathrm{Ca}_{2} \mathrm{GeO}_{4}$ (olivine form): some insights on anharmonicity. Phys. Earth Planet. Inter. 58, 141-154 (1989).

34. Chopelas, A. Thermal expansivity of lower mantle phases $\mathrm{MgO}$ and $\mathrm{MgSiO}_{3}$ perovskite at high pressure derived from vibrational spectroscopy. Phys. Earth Planet. Inter. 98, 3-15 (1996).

35. Zhai, S. et al. High-pressure X-ray diffraction and Raman spectroscopy of $\mathrm{CaFe}_{2} \mathrm{O}_{4}$-type $\beta-\mathrm{CaCr}_{2} \mathrm{O}_{4}$. Phys. Chem. Miner. 43, 307-314 (2016).

36. Sawada, $\mathrm{H}$. Electron density study of spinel: Magnesium titanium oxide $\left(\mathrm{Mg}_{2} \mathrm{TiO}_{4}\right)$. Mater. Res. Bull. 31, 355-360 (1996).

37. Angel, R. J. Equations of State. Rev. Mineral. Geochemistry 41, 35-59 (2000).

38. Yamanaka, T., Mine, T., Asogawa, S. \& Nakamoto, Y. Jahn-Teller transition of $\mathrm{Fe}_{2} \mathrm{TiO}_{4}$ observed by maximum entropy method at high pressure and low temperature. Phys. Rev. B 80, 134120 (2009).

39. Fei, Y., Frost, D., Mao, H., Prewitt, C. \& Hausermann, D. In situ structure determination of the high-pressure phase of $\mathrm{Fe}_{3} \mathrm{O}_{4}$. $A m$. Mineral. 84, 203-206 (1999).

40. Andrault, D. \& Bolfan-Casanova, N. High-pressure phase transformations in the $\mathrm{MgFe}_{2} \mathrm{O}_{4}$ and $\mathrm{Fe}_{2} \mathrm{O}_{3}-\mathrm{MgSiO}_{3}$ systems. Phys. Chem. Miner. 28, 211-217 (2001).

41. Reid, A. \& Ringwood, A. Newly observed high pressure transformations in $\mathrm{Mn}_{3} \mathrm{O}_{4}, \mathrm{CaAl}_{2} \mathrm{O}_{4}$, and $\mathrm{ZrSiO}_{4}$. Earth Planet. Sci. Lett. 6, 205-208 (1969)

42. Ye, L. et al. Compressibilities of $\mathrm{MnFe}_{2} \mathrm{O}_{4}$ polymorphs. Phys. Chem. Miner. 42, 569-577 (2015).

43. Irifune, T., Fujino, K. \& Ohtani, E. A new high-pressure form of $\mathrm{MgAl}_{2} \mathrm{O}_{4}$. Nature 349, 409-411 (1991).

44. Ono, S., Kikegawa, T. \& Ohishi, Y. The stability and compressibility of $\mathrm{MgAl}_{2} \mathrm{O}_{4}$ high-pressure polymorphs. Phys. Chem. Miner. 33, 200-206 (2006)

45. Åsbrink, S., Waśkowska, A., Olsen, J. \& Gerward, L. High-pressure phase of the cubic spinel $\mathrm{NiMn}_{2} \mathrm{O}_{4}$. Phys. Rev. B 57, 4972-4974 (1998).

46. Åsbrink, S., Waśkowska, A., Gerward, L., Olsen, J. \& Talik, E. High-pressure phase transition and properties of spinel $\mathrm{ZnMn}_{2} \mathrm{O}_{4}$. Phys. Rev. B 60, 12651-12656 (1999).

47. Muller-Buschbaum, H. The crystal chemistry of $\mathrm{AM}_{2} \mathrm{O}_{4}$ oxometallates. J. Alloys Compd. 349, 49-104 (2003).

48. Zhang, Y. et al. Spinel and post-spinel phase assemblages in $\mathrm{Zn}_{2} \mathrm{TiO}_{4}$ : an experimental and theoretical study. Phys. Chem. Miner. 44, 109-123 (2017).

49. Shannon, R. Revised Effective Ionic Radii and Systematic Studies of Interatomie Distances in Halides and Chaleogenides. Acta Crystallogr. A32, 751-767 (1976).

50. Mao, H., Xu, J. \& Bell, P. Calibration of the ruby pressure gauge to $800 \mathrm{kbar}$ under quasi-hydrostatic conditions. J. Geophys. Res. 91, 4673-4676 (1986).

51. Fei, Y. et al. Toward an internally consistent pressure scale. Proc. Natl. Acad. Sci. 104, 9182-9186 (2007).

52. Prescher, C. \& Prakapenka, V. DIOPTAS: A program for reduction of two-dimensional X-ray diffraction data and data exploration. High Press. Res. 35, 223-230 (2015).

53. Holland, T. \& Redfern, S. Unit cell refinement from powder diffraction data; the use of regression diagnostics. Mineral. Mag. 61, 65-77 (1997).

54. Gatta, G., Kantor, I., Boffa Ballaran, T., Dubrovinsky, L. \& McCammon, C. Effect of non-hydrostatic conditions on the elastic behaviour of magnetite: An in situ single-crystal X-ray diffraction study. Phys. Chem. Miner. 34, 627-635 (2007).

55. Wittlinger, J., Werner, S. \& Schulz, H. Pressure-induced order-disorder phase transition of spinel single crystals. Acta Crystallogr. Sect. B Struct. Sci. 54, 714-721 (1998).

56. Levy, D., Pavese, A., Sani, A. \& Pischedda, V. Structure and compressibility of synthetic $\mathrm{ZnAl}_{2} \mathrm{O}_{4}$ (gahnite) under high-pressure conditions, from synchrotron X-ray powder diffraction. Phys. Chem. Miner. 28, 612-618 (2001).

57. Errandonea, D., Kumar, R. S., Manjón, F. J., Ursaki, V. V. \& Rusu, E. V. Post-spinel transformations and equation of state in $\mathrm{ZnGa}_{2} \mathrm{O}_{4}$ : Determination at high pressure by in situ X-ray diffraction. Phys. Rev. B - Condens. Matter Mater. Phys. 79, 1-6 (2009).

58. Zhang, Y. et al. Physics and Chemistry of Minerals Equations of state of $\mathrm{Co}_{2} \mathrm{TiO}_{4}-\mathrm{Sp}, \mathrm{Co}_{2} \mathrm{TiO}_{4}-\mathrm{CM}$, and $\mathrm{Co}_{2} \mathrm{TiO}_{4}-\mathrm{CT}$, and their phase transitions: an experimental and theoretical study. (2018).

\section{Acknowledgements}

We acknowledge the constructive comments from two anonymous reviewers help to improve the quality of this work and the support from NSERC for SRS and ACW. In addition, we thank the support of GeoSoilEnviroCARS (Sector 13), which is supported by the National Science Foundation - Earth Sciences (EAR-1128799), and the Department of Energy, Geosciences (DE-FG02-94ER14466). This research used resources of the Advanced Photon Source, a U.S. Department of Energy (DOE) Office of Science User Facility operated for the DOE Office of Science by Argonne National Laboratory under Contract No. DE-AC02-06CH11357”. 


\section{Author contributions}

S. Shieh devised the project. C. Wang, S. Shieh and A. Withers wrote the manuscript. A. Djirar, T.Xie, J. Rumney, and C. Wang contributed to the experiments and data analyses. D. Zhang and S. Tkachev are the beamline scientists who helped the synchrotron X-ray diffraction experiments. X. Liu synthesized the sample. S. Shieh and A. Withers supervised the experiments and participated in data reduction.

\section{Competing interests}

The authors declare no competing interests.

\section{Additional information}

Correspondence and requests for materials should be addressed to C.-P.W. or S.R.S.

Reprints and permissions information is available at www.nature.com/reprints.

Publisher's note Springer Nature remains neutral with regard to jurisdictional claims in published maps and institutional affiliations.

(c) (i) Open Access This article is licensed under a Creative Commons Attribution 4.0 International License, which permits use, sharing, adaptation, distribution and reproduction in any medium or format, as long as you give appropriate credit to the original author(s) and the source, provide a link to the Creative Commons license, and indicate if changes were made. The images or other third party material in this article are included in the article's Creative Commons license, unless indicated otherwise in a credit line to the material. If material is not included in the article's Creative Commons license and your intended use is not permitted by statutory regulation or exceeds the permitted use, you will need to obtain permission directly from the copyright holder. To view a copy of this license, visit http://creativecommons.org/licenses/by/4.0/.

(c) The Author(s) 2020 